\title{
Manajemen Pengelolaan Sampah Studi Kasus di Bank Sampah Tirtarona Tlogomas Kota Malang
}

\author{
Yulianti, Rofi'ul Huda \\ Universitas Kanjuruhan Malang \\ yulianti@unikama.ac.id dan rofi'ulhuda@unikama.ac.id
}

\begin{abstract}
The BSM (Community Waste Bank) Unit Manager was a partner whose initial presence has not been able to utilize it according to the purpose of the establishment of the BSM Unit in the neighborhood of $R T / R W$ in the Tlogomas area. The purpose of the community partnership program (PKM) for waste managers in the Tlogomas region was to optimize the productivity of waste managers according to the purpose of establishing a waste bank organization in creating peace, and comfort in community life. The target specifically empowers waste managers $R T / R W$ as a partner of Malang City BSM in managing or managing small-scale waste independently. Starting from receiving community waste, sorting, administering, weighing, processing to the reporting stage as a form of evaluation of BSM Unit organizations to be able to contribute to their environment.The method used in addition to fostering the socialization of the importance of waste banks was also training and assistance in the utilization of waste. The results of the PKM activities were the organizational profile of the BSM Unit, site plans and repairs to the semipermanent building of the BSM Unit, training and assistance in utilizing waste recycling and marketing the products.
\end{abstract}

Keywords: Management; waste management; waste bank Malang

\begin{abstract}
Abstrak
Pengelola Unit BSM (Bank Sampah Masyarakat) adalah mitra yang keberadaan awalnya belum bisa memanfaatkan sesuai tujuan berdirinya Unit BSM di lingkungan RT/RW di wilayah Tlogomas. Tujuan program kemitraan masyarakat (PKM) pengelola sampah di wilayah Tlogomas ini untuk mengoptimalkan produktifitas pengelola sampah sesuai tujuan berdirinya organisasi bank sampah dalam menciptakan ketentraman, dan kenyamanan dalam kehidupan bermasyarakat. Target khususnya memberdayakan para pengelola sampah RT/RW sebagai mitra BSM Pusat Kota Malang dalam mengatur atau mengelola sampah secara mandiri skala kecil. Mulai penerimaan sampah warga, pemilahan, mengadministrasian, penimbangan, pengolahan sampai pada tahap pelaporan sebagai bentuk evaluasi organisasi Unit BSM untuk bisa memberikan kontribusi kepada lingkungannya. Metode yang digunakan selain pembinaan sosialisasi pentingnya bank sampah juga pelatihan dan pendampingan pemanfaatan limbah sampah. Hasil kegiatan PKM yakni profil organisasi Unit BSM, denah tempat dan perbaikan bangunan semi permanen Unit BSM, pelatihan dan pendampingan pemanfaatan daur ulang sampah dan pemasaran hasil produk.
\end{abstract}

Kata kunci: Manajemen; pengelolaan sampah; bank sampah Malang 


\section{A. PENDAHULUAN}

Berdasarkan keputusan Kementerian Lingkungan Hidup tahun 2008, Undangundang RI nomor 18 tahun 2008 tentang pengelolaan sampah Bab IV hak dan kewajiban Pasal 11, ditegaskan sebagai berikut:

"setiap orang berhak memperoleh pembinaan agar dapat melaksanakan pengelolaan sampah secara baik dan berwawasan lingkungan".

Hal ini sesuai dengan maksud dan tujuan berdirinya BSM Pusat kota selaku perintis berdirinya unit BSM di Kota Malang, yaitu 1) BSM membantu tugas Pemerintah Kota Malang dalam menyadarkan masyarakat untuk memilah dan mengelola sampah dari sumber (rumah tangga) dalam rangka mengurangi sampah yang masuk ke TPA Supiturang. 2) membuka ilmu pengelolaan sampah kepada masyarakat kota malang untuk menambah nilai ekonomis dan nilai lingkungan yang bersih dan sehat, 3) BSM membantu Pemerintah Kota Malang dalam membina, melatih dan mendampingi masyarakat Kota Malang yang tergabung dalam nasabah BSM dalam pengelolaan sampah 3R (Reuse, Reduse, Recycle) dari sumber rumah tangga (profil BSM Pusat Kota Malang 2018).

Kalimat di atas menegaskan bahwa Bank Sampah Masyarakat (BSM) yang menjadi unit BSM kota atau pusat bertujuan; 1) untuk membantu pemerintah kota Malang dalam menyikapi sampah, 2) membantu merubah mindset masyarakat bahwa sampah bisa jadi teman dan sebaliknya bisa jadi lawan dan 3) membuka lapangan kerja.

Bank sampah Tirtarona (BST) berdiri tahun 2011 dengan tujuan untuk menjaga lingkungan bersih dan sehat sebagaimana misi pemerintah kota Malang pemberdayaan lingkungan hidup.
Berdasarkan analisis situasi di BST terdapat permasalahan diantaranya; BST ini adalah bagian organisasi sosial yang berada di tingkat RW sebagai unit BSM pusat, sehingga ini termasuk dalam sasaran mitra masyarakat yang tidak produktif secara ekonomi, keberadaan BST awalnya produktif namun sekarang masih belum berjalan optimal dan belum dimanfaatkan sesuai tujuan berdirinya BSM, karena kepengurusan bank sampah yang dibentuk hanya sebagai syarat berdirinya Bank Sampah di lingkungan RT/RW, kurangnya keterampilan dan motivasi pengelola dalam menjalankan tugasnya sebagai pengelola BST, hal ini dikarenakan selain BST merupakan kegiatan sosial yang bukan profit oriented sehingga alasan faktor kesibukan kerja untuk sumber kebutuhan keluarga hidup ditengah-tengah perkotaan menjadi prioritas utama, dan BST sebagai sampingan dari kegiatan sosial.

Tujuan kegiatan PKM (Program Kemitraan Masyarakat) pengelola sampah ini adalah untuk mengoptimalkan produktifitas pengelola sampah sesuai tujuan berdirinya organisasi Bank Sampah dalam menciptakan ketentraman, dan kenyamanan dalam kehidupan bermasyarakat. Target khusus yang ingin dicapai dalam kegiatan PKM yakni memberdayakan para pengelola sampah RT/RW sebagai mitra BSM Pusat Kota Malang dalam mengatur atau memanage mulai penerimaan sampah warga, pemilahan, mengadministrasian, penimbangan, pengolahan sampai pada tahap pelaporan sebagai bentuk evaluasi organisasi BSM untuk bisa memberikan kontribusi kepada lingkungannya.

Berdasarkan hasil observasi dan diskusi dengan mitra maka dirumuskan beberapa masalah sebagai berikut: 


\section{a. Organisasi}

Minimnya pengetahuan tentang keorganisasian, keberadaan BSM dan program-programnya belum bisa dimanfaatkan dengan baik oleh warga. Organisasi BSM belum bekerja maksimal karena belum ada program kerja.

b. Manajemen

Minimnya pengalaman dan keterampilan pengelola BSM dalam mengolah sampah.

c. SDM

Kurangnya wawasan dan pengetahuan tentang pengelolaan sampah (BSM) karena kurang mendapatkan pelatihan dan pendampingan tentang pengolahan sampah.

d. Sarpras

Tempat untuk menimbun sampah sebagian ada yang masih terbuat dari bahan bambu, kalau musim hujan bocor dan kondisi kayunya lapuk.

Dari beberapa masalah tersebut maka tim pengabdi dan kedua mitra sepakat untuk menyelesaikan permasalahan sebagai berikut:

a. Pelatihan dan pendampingan tentang keorganisasian BSM, pelatihan dan pendampingan membuat program kerja.

b. Pelatihan dan pendampingan manajemen pengelolaan sampah dengan baik.

c. Pelatihan dan pendampingan pengolahan sampah

d. Pembangunan tempat penampungan

\section{B. PELAKSAAAN DAN METODE}

Kegiatan PKM Pengelola Sampah BSM Unit M.050 di wilayah Kelurahan Tlogomas. Waktu pelaksanaan mulai bulan Juli 2018 hingga bulan November 2018.
Latar belakang peserta BSM Unit M.050 adalah adanya kebijakan wali kota (2011) untuk pelaksanaan program pada masing-masing wilayah kelurahan di Kota Malang, yang didukung oleh program PKK di wilayah setempat. Pelaksanaan Unit BSM sepenuhnya diserahan kebijakan ketua RW setempat selaku penanggungjawab kegiatan Unit BSM.

Terbentuknya pengurus Unit BSM diserahkan sepenuhnya pada masing-masing RT/RW setempat. dan model pelaksanaan disesuaikan dengan kondisi lingkungan setempat yang terdiri ketua, sekretaris, bendahara dan anggota-anggota bagian daur ulang, pemilahan, pemasaran dan kompos.

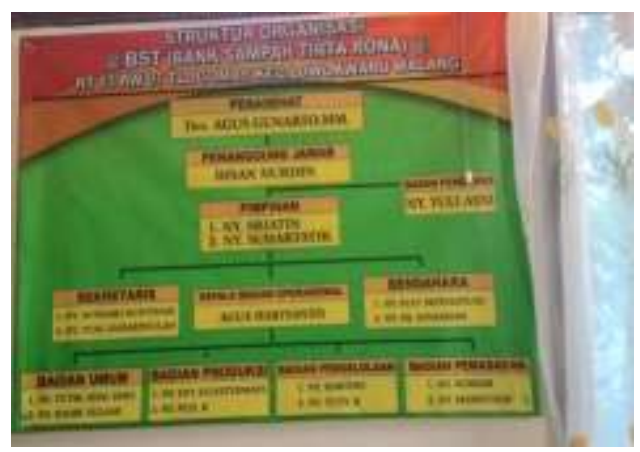

Gambar 1. Struktur BSM M.050 Tlogomas

Kegiatan yang dilakukan oleh pengurus awalnya mulai dari penerimaan sampah sampai pada penulisan di buku administrasi yang sudah disiapkan oleh BSM Pusat dalam memberdayakan Unit-unit BSM di Kota Malang. Dalam pelaksanaannya 59\% kondsi Unit BSM matisuri atau tinggal nama.

Untuk mengatasi permasalahan yang dihadapi, metode yang digunakan sebagai berikut:

1. Pembinaan pengurus dalam struktur organisasi Unit BSM, dan sosialisasi pentingnya program kerja dan tugas kerja yang harus dilakukan atau dilaksanakan dengan pendekatan. 


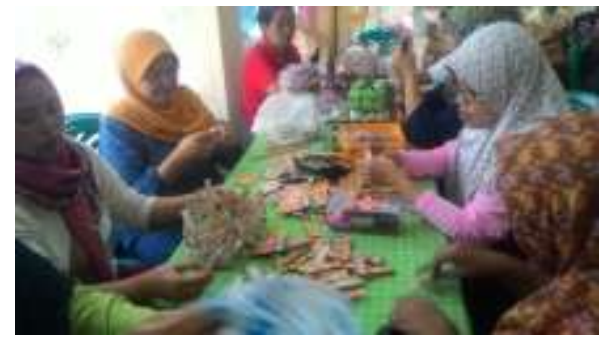

Gambar 2. Pembinaan pengurus BSM

2. Pengarahan dan pendampingan anggota BSM

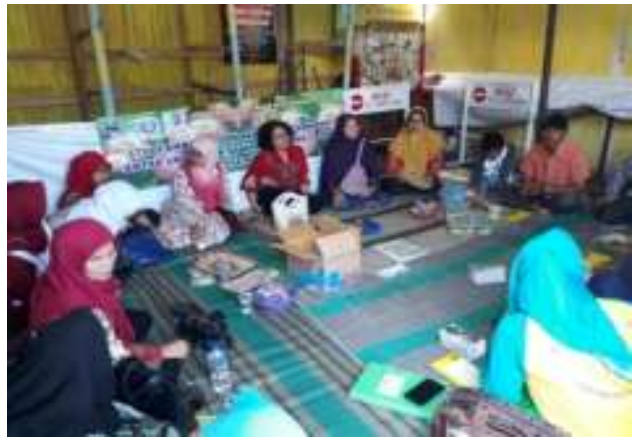

Gambar 2. Pengarahan dan pendampingan anggota BSM

3. Pelatihan, pendampingan dan monitoring BSM

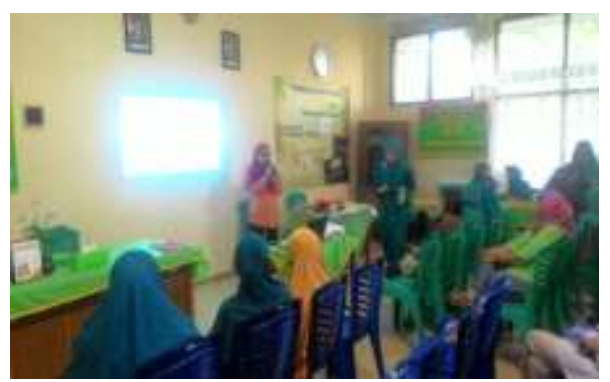

Gambar 3. Pelatihan dan monitoring BSM

4. Perbaikan dalam pengadaan tempat penampung sampah semi permanen

\section{HASIL DAN PEMBAHASAN}

Berdasarkan hasil analisis permasalahan mengenai manajemen pengelolaan sampah di
BSM M.050 wilayah Tlogomas didapatkan hasil sebagai berikut:

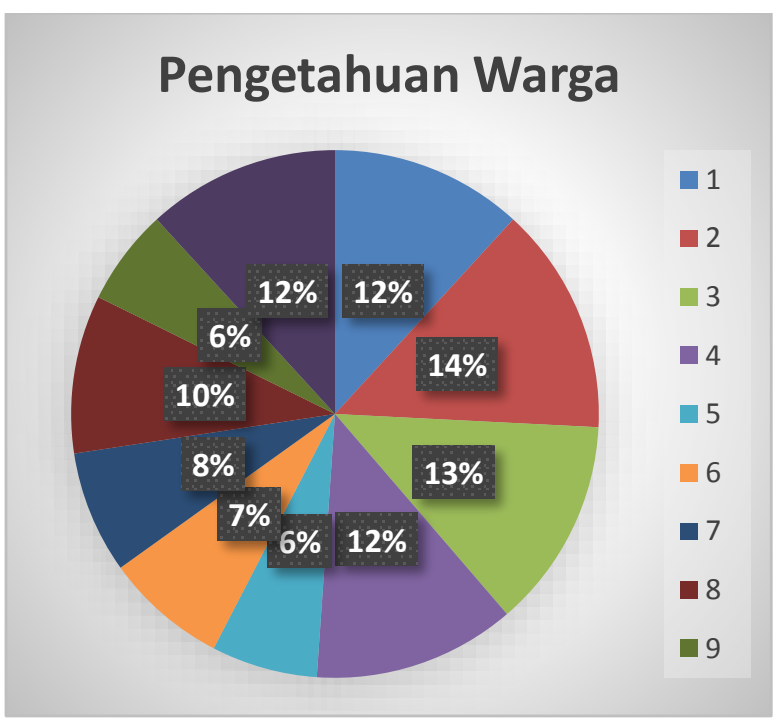

Gambar 4. Prosentase pengetahuan warga tentang sampah

Dari Gambar 4 di atas diperoleh hasil gambaran sikap warga terhadap sampah sebagai berikut: $10,8 \%$ warga selalu membuang sampah pada tempatnya, 5,4\% warga melakukan pemisahan sampah organik dan an organik, $10,3 \%$ upaya RT/RW pengelolaan fasilitas sanitasi BST, 0\% membiarkan sampah berserakan di sekitar rumah, $4 \%$ mengolah sampah rumah tangga menjadi pupuk, $7 \%$ melakukan pemilahan sampah sebelum sampah dikumpulkan ke BST, 7\% warga mau mengumpulkan sampah ke BST, 6\% menyediakan tempat pemilahan sampah di rumah, 6\% warga menyediakan tempat pemilahan sampah di rumah, 6\% warga melakukan memilah sampah sesuai jenisnya, 4\% ada usaha warga dalam menyikapi ketidak nyamanan dari sampah, 6,7\% mampu menegur anggota rumah yang tidak menjaga kebersihan, $10 \%$ memperhatikan tugas pengelola BST, 7\% warga memisahkan sampah kering dan basah di rumah, $6,7 \%$ mengumpulkan dan 
mengantarkan sampah kering ke BST, dan 9,9\% melaksanakan tata tertib kebersihan RT/RW. Data tersebut menegaskan hasil kegiatan Pengelola sampah Unit BSM di wilayah Tlogomas.

Hasil capaian kegiatan antara lain: 1) Struktur organisasi: dari struktur organisasi yang ada, selanjutnya disusun program kerja yang membangun program RT/RW dalam mengurangi jumlah sampah yang ada setiap keluarga dalam mewujudkan lingkungan bersih. 2) Sumber Daya Manusia: peserta pelatihan dan pendampingan adalah para pengurus/pengelola Unit BSM yang tanggap dalam menyikapi permasalahan yang ada sesuai sasaran kebutuhan Unit sampah skala RT/RW setempat. 3) Sarana dan prasarana: perbaikan dan pengembangan Unit BSM sebagai penyimpanan sampah, pelaksanaan daur ulang sampah dengan pembuatan kerajinan rumah tangga (Gambar 5). 4) Manajemen BSM: pembukuan hasil penimbangan sampah dan administrasi Unit BSM mulai penerimaan sampah, penimbangan, pemilahan, pengolahan dan penjualan barang. 5) Dan capaian kegiatan yang paling akhir adalah terbentuknya pertemuan rutin untuk menyikapi kesalah pahaman yang sering terjadi antara warga masyarakat dengan pengurus, masalah antar pengurus, dan kegiatan rutin pertemuan pengurus inti dengan nasabah.

Dampak positif kegiatan program kemitraan masyarakat adalah: 1)Pengelola sampah mitra 1 sudah bisa melaksanakan program kerja Unit BSM dan memiliki kegiatan pertemuan rutin antara nasabah sampah dan pengelola yang digunakan untuk koordinasi dan evaluasi bersama dalam pelaksanaan program kerja. 2) Meningkatnya jumlah nasabah yang awalnya Unit BSM hampir matisuri sekarang sudah mulai peduli sampah. 3) Adanya buku inventarisasi sebagai laporan kas hasil penjualan produk daur ulang sampah. 4) Kuantitas sampah bertambah karena perbaikan sarana tempat sampah semi permanen.

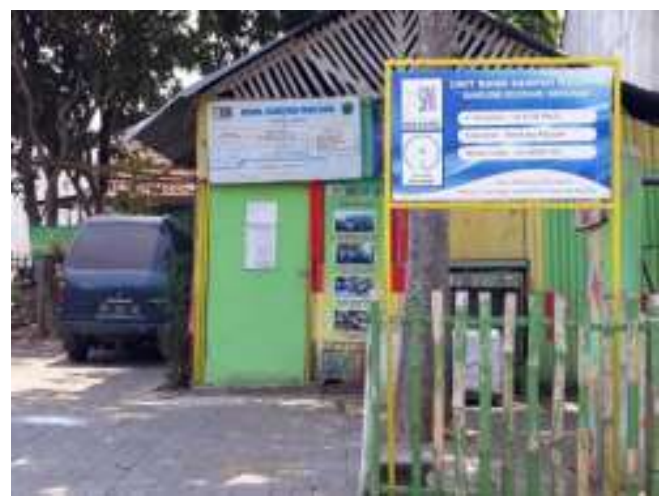

Gambar 5: Perbaikan bangunan sampah semi permanen

\section{PENUTUP}

\section{Simpulan}

Unit BSM di wilayah Tlogomas merupakan organisasi yang dibentuk oleh ketua RT/RW di lingkungan setempat guna mengurangi jumlah sampah yang menjadi permasalahan setiap keluarga, dan pengurus yang dibentuk sebagai mengelola sampah berdasarkan kesediaan peserta sebagai bentuk kegiatan masyarakat yang bersifat usaha sosial bukan milik perorangan.

Pemberdayaan pengelola sampah di wilayah kelurahan Tlogomas dilakukan melalui pembenahan mengenai keorganisasian unit, managemen pengelolaan Bank Sampah Tirtaruno (BST), perbaikan dan pengembangan sarana prasarana dan pembinaan SDM/ pengurus sampah.

\section{Saran}

Kegiatan Unit BSM akan berjalan dengan optimal selain didukung kebijakan ketua RT/RW setempat juga adanya respon warga dalam mengubah mainset atau pola pikir masyarakat pada fungsi BSM Unit sebagai wadah bisnis sampah supaya 
membantu ekonomi lingkungan masyarakat bisa kecukupan hidup dengan mengelola sampah.

\section{Ucapan Terima Kasih}

Saya ucapkan banyak terima kasih pada Kemenristekdikti dan jajaran pimpinan Universitas Kanjuruhan Malang serta temanteman Dosen dan mahasiswa yang mendukung serta pihak kelurahan, kader PKK dan pengelola BSM Tlogomas yang telah banyak membantu dalam keterlaksanaan pemberdayaan pengelola sampah di wilayah Kelurahan Tlogomas.

\section{E. DAFTAR PUSTAKA}

Rani, E. 2017. Pengaruh Program Bank Sampah Malang (Bsm) Terhadap Kontribusi Pendapatan Dan Lingkungan (Studi Kasus Kampung Bersinar 2015 RW. 03 Kelurahan Tlogomas Kota Malang). Skripsi. Fakultas Ekonomi dan Bisnis, Universitas Brawijaya Malang.

(http://jimfeb.ub.ac.id/index.php/jimfe b/article/view/3943). 